\title{
Macroscopic and Microscopic Study of the Testis after Ligation Of Head And Body Of Epididymis In Adult Male Albino Rats.
}

\author{
${ }^{1,}$ Dr. Pradeep Kumar murudkar, ${ }^{2}$ Ratnapriyanka janamala \\ ${ }^{I}$ Professor and Head, Dept of Anatomy, \\ ${ }^{2}$ Tutor, Dept of Anatomy, \\ ${ }^{1,2}$ Khaja BandaNawaz Institute of Medical Sciences, Gulbarga, Karnataka.
}

\begin{abstract}
The present work is done to study the effects after ligation of head and body of epididymis and to observe the changes and to answer the questions posed by someone before undergoing ligation at different levels. In the present experimental series effects were studied from 30 days onwards, as the main aim was to see the long term effects in adult male albino rats. The animals selected were albino rats because of their continuous spermatogenesis and ease of availability and can withstand the chloroform anesthesia and operative procedure. In the present study the volume of testis on the operated side showed gradual decrease in the size when compared to the contralateral control after the ligation of head of epididymis with the effect from $3 \mathrm{rd}$ day to 30 th day but after the ligation of body of epididymis there were no changes observed in the first 9 days and volume of testis gradually decreased with effect from 12 th day and changes were noted up to 30 th day in comparision to contralateral control.The observations revealed that ligation of body and head of epididymis caused progressive atrophy of the testis and degeneration of seminiferous tubules and seminiferous epithelium and relative prominence of interstitial tissue. The author concluded that ligation of excurrent duct system at a higher level i.e. head and body of epididymis results in back pressure and causes progressive changes in the testis.
\end{abstract}

Keywords: Epididymis, fertility, adult male albino rats, sexual potency.

\section{Introduction}

Ligation of excurrent duct system is performed in India, mainly as permanent family planning measure to prevent further conceptions. Vasectomy is also proposed for alleviating senile prostatic hypertrophy, and has been used in connection with prostatectomy to prevent retrograde infection going to epididymis. It is also indicated for disputed rejuventive effects in males.Every man who undergoes operations will have a number of doubts in his mind and often, asks the doctor about the consequences of the operation.

The questions usually posed were

1. What happens to the sperms produced if they are prevented from ejaculation?

2. What happens to sexual potency after operation?

3. Unfortunately if the children die is the operation reversible?

Elaborate experimental work was done to study the effects of ligation of excurrent duct system of testis, by ligating at different levels.Experiments were performed in different species, such as rabbits, mice guinea pigs and dogs. And also testicular and epididymal biopsies were studied after vasectomy in men. The literature on the effects on vasectomy is not unanimous. In the recanalisation operation also, even though the anatomical reanastomosis of the vas deferns is possible, it is not possible to restore normal fertility in all the cases. In only 5 to $10 \%$ of cases it proved to be successful.The present work is done to reassess the effects of ligation of excurrent duct system of testis at different levels to study the long term effects of ligation of head and body of epididymis which has been studied only by few people, and to answer some of the usual questions posed by some men before undergoing ligation. In the present experimental series, the effects were studied 30 days onwards, as the aim was to see the long term effects. The animals selected for the present study were albino rats, because the spermatogenesis in them is a continuous process and they are easily available and they also with stand the chloroform anaesthesia and operative procedure well.

\section{Materials And Methods}

The present study was based on the experiments performed on 20 mature male albino rats weighing 150-200 gms. Two experiments were performed by ligating the duct system of the testis at various levels as follows. 
A. Ligation of caput epididymis in 10 rats

B. Ligation of body of epididymis in 10 rats.

Ligation was done on the right side so that left testis and epididymis could serve as control, the rat undergoing operation was weighed and weight recorded. The operations were performed under sterile conditions using chloroform anaesthesia. The rat was anaesthetized by keeping it under glass bell jar putting a small piece of cotton soaked in chloroform. Within few minutes the rat becomes unconscious. The anterior abdominal wall was shaved and cleaned with spirit. The operation was performed by taking a median suprapubic incision 1.25 long and muscular and peritoneal layers were cut. The right testis was gently squeezed out of scrotum and delivered through the abdominal wound and ligatures were put as per type of operation.

Experiment A-Ligature was put on the head of the epididymis below the level of vasa-efferentia.Experiment BLigature was applied on the middle of the body of the epididymis After ligation the testis was replaced in to scrotum, care was taken not to allow the testis to remain in the abdominal cavity. Then peritoneal and muscular layers of the anterior abdominal wall were sutured, using ' 00 ' chromic cat gut. Skin was closed by interrupted sutures using black cotton thread. Animal recovered from anaesthesia within few minutes after closing the abdomen .Then it was transferred to its cage where sterile cotton was spread. After one hour, water was given to animal; it started taking its regular feed after 3 hours. Skin sutures were removed after 8 days, in the animals which were observed for more 9 days, wound infection was seen in only 3-4 rats.In experiments number ' $A$ ' and ' $B$ ' animals were sacrificed at the interval of 3 days up to 30 days, considering the day of operation as ' 0 '., the animals weight was recorded before the sacrifice. The gonads and the epididymis were separated trimmed free of adipose tissue and connective tissue and the length and volume of testis were recorded. The volume and weight of the epididymis were also recorded. The testis and epididymis were fixed in $10 \%$ formal saline. For histological investigation, the tissues were processed and blocks were prepared using paraffin wax. The tissues were cut at 6-7 microns thickness and stained with Haematoxylin and eosin. The sections of testis and epididymis were examined,

1. To see the diameter of seminiferous tubules:

2. To the study the changes if any in germinal epithelium, interstitial tissue in the testis and

3 . To see the tubular diameter and content of the epididymal tubules.

4. To study the lining epithelium and intertubular tissues in the epididymis

The sections of cysts were also taken and stained to study the histological appearance. The above findings were compared with sections of the control testis and epididymis.

\section{Results}

In the present study 20 mature male albino rats were subjected to ligation at head of epididymis and body of epididymis and following observations were recorded at the intervals of 3 days up to 30 days and were represented in Table no. 1 and Table no. 2 and their percentage of increase or decrease in the volume of testis on the operated side in comparison to contralateral control following ligation of head and body of epididymis were represented in Table no. 3 and Table no. 4

\subsection{Statistical application}

The present work could be worked out statistically to prove any hypothesis related to two experiments conducted. For this purpose the $t$ test for independent samples can be applied and could be correlated to the effects observed. The observations of the different experiments could be worked out stastically, to prove whether there is any significance or not.

The hypothesis is:

1. Ligation of head of epididymis will affect the testis.

2. Ligation of body of epididymis cause less damage in the testis.

These hypotheses could be negative or positive. In order to prove these hypotheses each experiment can be worked out statically by applying $t$ test independent samples. The hypothesis could be negative or positive. In order to prove these hypothesis each experiment can be worked out statistically by applying $t$ test applying $t$ test for independent samples.

The formulas to be used are:

$$
\text { 1. } \delta \mathrm{X}_{1}-\mathrm{X}_{2}=. \mathrm{X}_{1}^{2}+\mathrm{X}_{2}^{2}\left(1 / \mathrm{n}_{1}+1 / \mathrm{n}_{2}\right)
$$

\section{Where}

$\delta \mathrm{X}_{1}-\mathrm{X}_{2}=$ the standard error of the difference between two means.

$\mathrm{n}_{1} \quad=$ the number of cases in group 1

$\mathrm{n}_{2} \quad=$ the number of cases in group 2 
$\sum \mathrm{X}_{1}{ }^{2}=$ the sum of squared deviation scores in group 1 .

$\sum X_{2}{ }^{2}=$ the sum of squared deviation scores in group 2

And

$2 \quad \delta \mathrm{X}_{1}-\mathrm{X}_{2}$

$\delta X_{1}-X_{2}$

Where,

$\delta \mathrm{X}_{1}-\mathrm{X}_{2}=$ the observed difference between two means

$\delta \mathrm{X}_{1}-\mathrm{X}_{2}=$ the standard error of the difference between two means.

Or,

The t-ratio formula in more comp form by including the above two formulas:

3. $\mathrm{t}=$ $\mathrm{X}_{1}-\mathrm{X}_{2}$

$$
\begin{aligned}
& \left(\sum \mathrm{X}_{1}{ }^{2}+\sum \mathrm{X}_{2}{ }^{2}\right) \quad\left(1 / \mathrm{n}_{1}+1 / \mathrm{n}_{2}\right) \\
& \mathrm{n}_{1}+\mathrm{n}_{2}-2
\end{aligned}
$$

The observed ratio should be compared with the expected and conclusion of significance can be drawn.

Expected ration can be had from the t-table, by reading the columns of different levels, i.e., 0.1, 0.05, 0.01 and

0.001 , against the row of degrees of freedom.

The degrees of freedom can be calculated as follows.

$\mathrm{df}=\mathrm{n}_{1}+\mathrm{n}_{2}-2$

Where,

df $=$ degrees of freedom

$\mathrm{n}_{1}=$ number of cases in group 1

$\mathrm{n}_{2}=$ number of cases in group 2

\subsection{Ligation of head of epididymis}

\section{Discussion}

Experiment ligation of head of the epididymis was done by many workers and the effects on the testis and epididymis were interpreted in many ways. The observations made by Macmillan and Harrison ${ }^{5}$ and Reddy ${ }^{8}$ such as, testicular atrophy and degeneration of seminiferous tubules following high epididymal obstruction and increase in interstitial tissue were confirmed in this study, and observed similar changes after sub capital ligation of epididymis. The author also observed that the permanent testicular destruction was associated with leydig cell hyperplasia.Baillie ${ }^{1}$ did not notice any change in the testis following high epididymal ligation. But in the present study there was severe degeneration of seminiferous tubules within 24 days.Ballie ${ }^{2}$ in his study of epididymal ligation observed two phases of testicular response, the first being testicular swelling of abrupt on set which lasted for 2 weeks. Followed by compensatory phase at which testicular weight became normal. But in authors experiments the testicular swelling lasted for 9 days followed by atrophy of testis and then severe degeneration of seminiferous tubules. There was relative increase of interstitial tissue shedding of seminiferous epithelium and its phagocytosis, which confirmed the observation of Ballie.Gaddum and Glover ${ }^{3}$ and Reddy ${ }^{8}$ studied the high ligation of the epididymis and noted discrete cream coloured patches of the epididymis and noticed white patches on the surface of the testis, due to excessive swelling of the seminiferous tubules. In the present work,observation after high ligation, cream coloured granulomatous nodules seen on of epididymis above the ligation and cream coloured patches were seen on the surface of the testis. The macroscopic changes noticed agreement with the above investigators.Histologically seminiferous tubules showed 2-3 fold increase in diameter which reached its maximum in 6 days, following which decrease in the diameter was observed. This later become tortuous,irregular and collapsed and only tubular outline could be seen of 18 day. The seminiferous tubules showed complete degeneration in 21 day. The epididymis above the ligation was distended with cream coloured nodules on its surface. Histologically it showed dilation of tubules filled clumps of spermatozoa and presence of phagocytic cells. The lining epithelium became flat, nuclei and cilia were lost.

\subsection{Ligation of body of epididymis}

Glover ${ }^{4}$ noticed considerable distension of the epididymis above ligation. He also noticed prominent vivid cream coloured convulsions of the tubule and patches of cream coloured area both on the body and head of the epididymis. Histologically the epididymal tubules showed distension, with flattening and loss of cilia of the lining epithelium. The testis showed the distension of the seminiferous tubules and spermatogenesis remained unchanged till 21 days.In authors series the epididymal changes were similar to those observed by Glover ${ }^{4}$ but spermatogenesis was effected in the middle of $2^{\text {nd }}$ week with varying degrees of shedding of seminiferous epithelium into the lumen.Gaddum and Glover ${ }^{3}$ and Reddys ${ }^{8}$ observations were in complete agreement with those of authors observations after ligation of the body of the epididymis. The author observed over distension of the epididymis ,proximal to the ligation ,development of discrete cream coloured patches, where the tubule 
was excessively distended and conspicuous convulsions of the ductus epididymis on the body and head of the epididymis. These observations were similar to those observed by above mentioned investigators Paufler and Foote ${ }^{7}$ in their series of experiments noticed severe effects following the ligation of the middle of the epididymis. They observed reductions in the weight of the testis ,decrease in the diameter of the seminiferous tubules, accompanied by disruption of seminiferous epithelium. They have noticed the renewal of spermatogenesis with testicular adaption after 12 weeks. The epididymis was also increased above the ligation in their series.In the author series ,he noticed early increase in the testicular size,followed by decrease in its size. The seminiferous tubules were also increased in diameter following which there was a decrease in their diameter with disruption of seminiferous epithelium. Histologically epididymis showed an increase in diameter of its tubules occupied by masses of spermatozoa with changes in its lining epithelium and evidence of phagocytosis in their lumina.Low ligation of epididymis caused delayed effects on testis in comparison to the high ligation and ligation of vasa efferentia.

Ligation of the body did not cause any change in size of testis till 9 day. But later it increased in size till 18 day, following which there was a gradual decrease in size.Finally testicular size was reduced to half by 30 th day.Histologically there was no change in the seminiferous tubular diameter till 6 th day, but epithelium started drifting away from the basement membrane. After 9 th day the seminiferous tubules showed gradual increase in diameter,first in the peripheral region,followed by those in the central region. The degeneration o $\mathrm{fthe} \mathrm{seminiferous} \mathrm{epithelium} \mathrm{was} \mathrm{first} \mathrm{seen} \mathrm{in} \mathrm{the} \mathrm{peripheral} \mathrm{tubules} \mathrm{with} \mathrm{complete} \mathrm{shedding} \mathrm{of} \mathrm{its} \mathrm{epithelium} \mathrm{at}$ $15^{\text {th }}$ day. By 30 day the seminiferous tubules were shrunken,irregular and most of them were lined by a single layer of cells with presence of gaint cells in their lumina.The epididymal changes after low ligation resembled those of high ligation, with dilation of duct of epididymis, above ligation and development of vivid cream coloured patches on the body and head of epididymis. Appearance of conspicuous convulsion of the dilated,tortuous duct of the epididymis were normally seen.Histologically the epididymal tubules were distended and filled with clumps of spermatozoa in their lumen. Evidence of phagocytosis was also observed. The lining epithelium became flat with flat nuclei and loss of cilia. The duct of epididymis was also distended to such an extent resembling structurally to that of a spermatic granuloma. This is observed in the present series of vasectomy, which developed on the cut testicular end of the vas.

\section{Conclusion.}

Two groups of rats were subjected to 2 experimental procedures by ligating the excurrent duct system of testis at different levels and effects studied both macroscopically and microscopically in testis and epididymis. The operations were performed unilaterally on the right side, the contralateral left testis and epididymis serving as control.The following are the conclusions observed by the author Ligation of head and body of the epididymis caused progressive atrophy of the testis and degeneration of seminiferous tubules and seminiferous epithelium and relative prominence of interstitial tissue. Epididymal changes above the ligation included dilation of tubules, filled with spermatozoa and evidence of phagocytosis and flattening of lining epithelium with loss of cilia.The author concluded that ligation of excurrent duct system at a higher level i.e. head and body of epididymis results in back pressure and causes progressive changes in the testis.

\section{References}

[1] Baille A.H. The biology of the leydig cell,histochemical and histological changes following high epididymal ligation.J.Endocri. 20:1960;339-334.

[2] Baille A.H. Observations comparing the effects of epididymal obstruction at various levels on the mouse testis with those Isohaemia.J.Anat. 96:1962; 335-354.

[3] Gaddum P. and T.D.Glover. Some reactions of rabbit spermatozoa to ligation of epididymis. J.Reprod. Fertil. 9:1965; 119-130.

[4] Glover T.D. The response of rabbit spermatozoa to artificial cryptorchidism and ligationof the epididymis. J.Endocrin. 23:1962; 317-328.

[5] Harrison R.G. and Macmillan. The response of rabbit spermatozoa to artificial cryptorchidism and ligationof the epididymis. J.Endocrin. 23:1954; 317-328.

[6] Paufler S.K. and R.H.Foote. Spermatogenesis in rabbit following ligation of epididymis at different levels. Anat.Rec. 164:1969a; 339-348.

[7] Paufler S.K. and R.H.Foote. Spermatogenesis and receptopn in sexually active rabbits with epididymal ligatures.Proc.Soc.Exp.Biol.Med. 131:1969b; 1179-1183.

[8] Reddy K., Shrinivas. Study of testis and epididymis of vasectony and ligation of excurrent duct system in albino rats (from Desertation copy of Osmania University).1975. 
Table 1: showing the observations after the ligation of head of epididymis.

\begin{tabular}{|c|c|c|c|c|c|c|}
\hline Days & \multicolumn{3}{|c|}{ Macroscopic changes } & \multicolumn{3}{|c|}{ Microscopic changes } \\
\hline & Testis & Enididymis & $\begin{array}{l}\text { Increase } \\
\text { in volume }\end{array}$ & Seminiferopss tubules & \begin{tabular}{|l|} 
Interstitial \\
tissue
\end{tabular} & Enididzmal tubules \\
\hline 3 & $\begin{array}{l}\text { slight } \\
\text { enlargement }\end{array}$ & $\begin{array}{l}\text { Cystic enlargemant of } \\
\text { apididymis above the point of } \\
\text { ligation }\end{array}$ & $20 \%$ & $\begin{array}{l}\text { Slight increase in diameter of peripheral } \\
\text { seminiferous tubules. The lining } \\
\text { epithelium has not changed }\end{array}$ & $\cdot$ & $\begin{array}{l}\text { Enlarged in diameter filled with } \\
\text { clumps of spermatozos. The lining } \\
\text { epithelium of the tubules were } \\
\text { becoming flattened }\end{array}$ \\
\hline 6 & $\begin{array}{l}\text { Enlarged in siza } \\
\text { and tense in } \\
\text { consistancy }\end{array}$ & $\begin{array}{l}\text { Epididuymis was also enlarged } \\
\text { above the point ofligation }\end{array}$ & $30 \%$ & $\begin{array}{l}\text { No obvious increase in the diamater of } \\
\text { seminiferous tubules }\end{array}$ & Normal & $\begin{array}{l}\text { Similar changes seen at } 3 \text { days } \\
\text { with loss of cilia at lining } \\
\text { epithelium }\end{array}$ \\
\hline 9 & $\begin{array}{l}\text { Enormous } \\
\text { increase in sizz }\end{array}$ & $\begin{array}{l}\text { Cream coloured nodules were } \\
\text { seen }\end{array}$ & $60 \%$ & $\begin{array}{l}\text { Dilated and tortuous, seminiferous } \\
\text { epithelium into its lumenwas seen } \\
\text { showing signs of degeneration }\end{array}$ & - & $\begin{array}{l}\text { Similar changes seen at } 3 \text { days, The } \\
\text { confluence of adjacant tubulas } \\
\text { were seen broken septapartially } \\
\text { separating the enlarged tubules }\end{array}$ \\
\hline 12 & Reduction in size & $\begin{array}{l}\text { Cystic enlargemant of } \\
\text { spididymis above thepoint of } \\
\text { ligation }\end{array}$ & $15.6 \%$ & $\begin{array}{l}\text { Dilated and distended tubules were sean in } \\
\text { various stages of degeneration. The } \\
\text { shedding of lining epithelium into the } \\
\text { lumen was quite obvious }\end{array}$ & Hoperemic & Similar changes seen at 3 days. \\
\hline 15 & Reduction in size & $\begin{array}{l}\text { Cystic enlargament of } \\
\text { epididymis sbove thepoint of } \\
\text { ligation }\end{array}$ & $13 \%$ & Similar changes seen at 12 days. & Howperemic & Similar changes seen at 3 , days. \\
\hline 18 & $\begin{array}{l}\text { Reduction in size } \\
\text { and less turgid }\end{array}$ & $\begin{array}{l}\text { Cystic enlargemant of } \\
\text { epididymis above the point of } \\
\text { ligation }\end{array}$ & $35 \%$ & $\begin{array}{l}\text { Degeneration of tubules whichwere } \\
\text { distorted }\end{array}$ & Hivperamic & $\begin{array}{l}\text { Tubulas were recuced in diamater, } \\
\text { fillad with spermatozoa; the lining } \\
\text { epithelium has become flattenad. } \\
\text { Infiltration of lymphocytes were } \\
\text { seen the lumen. Intertubular } \\
\text { fibrosis wereseen. }\end{array}$ \\
\hline 21 & $\begin{array}{l}\text { Reduction in sizz } \\
\text { and lass turgid }\end{array}$ & $\begin{array}{l}\text { Cystic enlargement of } \\
\text { apididymiss above thepoint of } \\
\text { ligation }\end{array}$ & $40 \%$ & $\begin{array}{l}\text { Degeneration of tubules which were } \\
\text { distortad lining epithalium was disturbed } \\
\text { and was being shadinto thelumen of } \\
\text { tubules }\end{array}$ & Hivperamic & Similar changes seen at 18 days. \\
\hline 24 & Reduction in sizz. & $\begin{array}{l}\text { Cream coloured Cystic } \\
\text { enlargement of epididvmis } \\
\text { above the point ofligation }\end{array}$ & $35 \%$ & $\begin{array}{l}\text { Testis showed empty seminiferous } \\
\text { tubules, lining ep ithelium was disturbed } \\
\text { and reduced in number of layers with } \\
\text { plenty of vacuoles appearing in the lining } \\
\text { epithelium }\end{array}$ & Hivperemic & $\begin{array}{l}\text { Epididymal tubules were empty } \\
\text { with infiltration of lymphocytes. } \\
\text { Intertubular fibrosis was sean. }\end{array}$ \\
\hline 27 & Reduction in size. & $\begin{array}{l}\text { Cream coloured Cystic } \\
\text { enlargement of epididymis } \\
\text { above the point ofligation }\end{array}$ & $55 \%$ & Similar changes seen at 24 days. & Hivperemic & Similar changas seen at 24 days. \\
\hline 30 & - & $\begin{array}{l}\text { Cystic enlargement of } \\
\text { epididymis above thepoint of } \\
\text { ligation }\end{array}$ & $60 \%$ & $\begin{array}{l}\text { Testis showed varying degrees of } \\
\text { degeneration the outline of seminiferous } \\
\text { tubules indistinct. }\end{array}$ & $\begin{array}{l}\text { Distended } \\
\text { bloodyessels } \\
\text { were seen in the } \\
\text { interstitial tis sue }\end{array}$ & $\begin{array}{l}\text { Changes in the epididymis were } \\
\text { same as seen in } 24 \text { and } 27 \text { days } \\
\text { specimens }\end{array}$ \\
\hline
\end{tabular}


Table 2: showing the observations after the ligation of body of epididymis.

\begin{tabular}{|c|c|c|c|c|c|c|c|c|}
\hline \multirow[t]{2}{*}{ Days } & \multicolumn{3}{|c|}{ Macroscopic changes } & \multicolumn{3}{|c|}{ Microscopic changes } & \multirow[b]{2}{*}{$\begin{array}{l}\text { Lining } \\
\text { epithelium }\end{array}$} & \multirow[b]{2}{*}{ Lumen } \\
\hline & Testis & Epididymis & $\begin{array}{l}\text { Inc } \\
\text { rea } \\
\text { se } \\
\text { in } \\
\text { vol } \\
\text { um } \\
\text { e }\end{array}$ & Seminiferous tubules & $\begin{array}{l}\text { Interstiti } \\
\text { al tissue }\end{array}$ & Epididymal tubules & & \\
\hline 3 & Normal & $\begin{array}{l}\text { Distended just proximal to } \\
\text { site of ligation }\end{array}$ & - & Normal & Normal & $\begin{array}{l}\text { Dilated,studded with } \\
\text { sperms }\end{array}$ & $\begin{array}{l}\text { Flattened, cilia of } \\
\text { the lining } \\
\text { epithelial cells } \\
\text { were lost }\end{array}$ & - \\
\hline 6 & Normal & $\begin{array}{l}\text { Distended just above the } \\
\text { site of ligation }\end{array}$ & - & $\begin{array}{l}\text { Normal, in some } \\
\text { tubules epithelium was } \\
\text { shedding into lumen }\end{array}$ & Normal & $\begin{array}{l}\text { Dilated and distended with } \\
\text { clumps of spermatozoa }\end{array}$ & Flattened & $\begin{array}{l}\text { Infiltration of lymphocytes } \\
\text { was seen in the lumen }\end{array}$ \\
\hline 9 & Normal & $\begin{array}{l}\text { Similar changes seen at } 6 \\
\text { days. }\end{array}$ & - & $\begin{array}{l}\text { Similar changes seen } \\
\text { at } 6 \text { days. }\end{array}$ & Normal & $\begin{array}{l}\text { Similar changes seen at } 6 \\
\text { days. }\end{array}$ & Flattened & $\begin{array}{l}\text { Similar changes seen at } 6 \\
\text { days. }\end{array}$ \\
\hline 12 & $\begin{array}{l}\text { Increas } \\
\text { e in } \\
\text { size } \\
\text { and } \\
\text { volume }\end{array}$ & $\begin{array}{l}\text { Showed granulomatous, } \\
\text { cream coloured nodules } \\
\text { above the ligation,head of } \\
\text { epididymis was distended }\end{array}$ & $\begin{array}{l}20 \\
\%\end{array}$ & $\begin{array}{l}\text { Increase in diameter } \\
\text { with various degrees } \\
\text { of shedding of } \\
\text { epithelium in to lumen }\end{array}$ & $\begin{array}{l}\text { Hyperem } \\
\text { ic }\end{array}$ & Dilated & Flattened & $\begin{array}{l}\text { Infiltration of mononuclear } \\
\text { cells was seen in the lumen }\end{array}$ \\
\hline 15 & $\begin{array}{l}\text { Increas } \\
\text { e in } \\
\text { size } \\
\text { and } \\
\text { volume }\end{array}$ & $\begin{array}{l}\text { Similar changes seen at } 12 \\
\text { days. }\end{array}$ & $\begin{array}{l}42 \\
\%\end{array}$ & $\begin{array}{l}\text { Similar changes seen } \\
\text { at } 12 \text { days. }\end{array}$ & $\begin{array}{l}\text { Hyperem } \\
\text { ic }\end{array}$ & Dilated & Flattened & $\begin{array}{l}\text { Similar changes seen at } 12 \\
\text { days. }\end{array}$ \\
\hline 18 & $\begin{array}{l}\text { Marked } \\
\text { enlarge } \\
\text { ment } \\
\text { and } \\
\text { increas } \\
\text { e in } \\
\text { volume }\end{array}$ & $\begin{array}{l}\text { Cream coloured patches } \\
\text { were seen on the head of } \\
\text { the epididymis }\end{array}$ & $\begin{array}{l}40 \\
\%\end{array}$ & $\begin{array}{l}\text { Increase in } \\
\text { diameter,irregular } \\
\text { shape with various } \\
\text { degrees of shedding of } \\
\text { epithelium in to lumen }\end{array}$ & $\begin{array}{l}\text { Hyperem } \\
\text { ic }\end{array}$ & $\begin{array}{l}\text { Disintegration of } \\
\text { epididymal tubules, some } \\
\text { of them were filled with } \\
\text { degenerating sperms with } \\
\text { infiltration of phagocytic } \\
\text { cells. }\end{array}$ & - & - \\
\hline 21 & $\begin{array}{l}\text { Slight } \\
\text { reducti } \\
\text { on in } \\
\text { size }\end{array}$ & $\begin{array}{l}\text { Distension of epididymis } \\
\text { just above the site of } \\
\text { ligation }\end{array}$ & $\begin{array}{l}10 \\
\%\end{array}$ & $\begin{array}{l}\text { Germinal epithelium } \\
\text { was restricted just to } 1 \\
\text { or } 2 \text { layers in many } \\
\text { tubules. }\end{array}$ & $\begin{array}{l}\text { Hyperem } \\
\text { ic }\end{array}$ & $\begin{array}{l}\text { Epididymis showed similar } \\
\text { changes seen at } 18 \text { days. }\end{array}$ & - & - \\
\hline 24 & $\begin{array}{l}\text { Slight } \\
\text { reducti } \\
\text { on in } \\
\text { size }\end{array}$ & $\begin{array}{l}\text { Distension of epididymis } \\
\text { above the site of ligation }\end{array}$ & $\begin{array}{l}13 \\
\%\end{array}$ & $\begin{array}{l}\text { Similar changes seen } \\
\text { at } 21 \text { days. }\end{array}$ & $\begin{array}{l}\text { Hyperem } \\
\text { ic }\end{array}$ & $\begin{array}{l}\text { Epididymis showed similar } \\
\text { changes seen at } 18 \text { days. }\end{array}$ & - & - \\
\hline 27 & $\begin{array}{l}\text { Reduce } \\
\text { d in } \\
\text { size } \\
\text { and } \\
\text { less } \\
\text { turgid }\end{array}$ & $\begin{array}{l}\text { Head of epididymis was } \\
\text { distended,cream coloured } \\
\text { cyst was seen near ligation }\end{array}$ & $\begin{array}{l}25 \\
\%\end{array}$ & $\begin{array}{l}\text { Seminiferous } \\
\text { epithelium was almost } \\
\text { restricted to single } \\
\text { layer in most o tubules } \\
\text { and lumen appeared } \\
\text { empty }\end{array}$ & $\begin{array}{l}\text { Hyperem } \\
\text { ic }\end{array}$ & $\begin{array}{l}\text { Epididymal tubules were } \\
\text { empty }\end{array}$ & - & $\begin{array}{l}\text { Cyst showed degenerating } \\
\text { sperms with infiltration of } \\
\text { lymphocytes }\end{array}$ \\
\hline 30 & $\begin{array}{l}\text { Marked } \\
\text { reducti } \\
\text { on in } \\
\text { size }\end{array}$ & $\begin{array}{l}\text { Cystic enlargement of head } \\
\text { of epididymis }\end{array}$ & $\begin{array}{l}51 \\
\%\end{array}$ & $\begin{array}{l}\text { Similar changes seen } \\
\text { at } 27 \text { days }\end{array}$ & $\begin{array}{l}\text { Similar } \\
\text { changes }\end{array}$ & $\begin{array}{l}\text { Similar changes seen at } 27 \\
\text { days }\end{array}$ & - & - \\
\hline
\end{tabular}

Table :3 Showing percentage of increase or decrease in the volume of testis on the operated side in comparison to contralateral control following ligation of head epididymis

\begin{tabular}{|l|l|l|l|l|}
\hline No of days & Control $\begin{array}{r}\text { Volume of testis in ml } \\
\text { Operated }\end{array}$ & $\begin{array}{l}\text { Volume of the } \\
\text { experimental testis } \\
\text { expressed as \% of } \\
\text { control }\end{array}$ & $\begin{array}{l}\text { Percentage of } \\
\text { increase or } \\
\text { decrease in size }\end{array}$ \\
\hline 3 & 1.5 & 1.80 & 120.00 & +20.00 \\
\hline 6 & 1.5 & 1.95 & 130.00 & +30.00 \\
\hline 9 & 1.5 & 2.40 & 160.00 & +60.00 \\
\hline 12 & 1.3 & 1.10 & $\mathbf{8 4 . 4 0}$ & -15.60 \\
\hline 18 & 1.5 & 9.98 & 65.00 & -35.00 \\
\hline 21 & 1.0 & 0.60 & 60.00 & -40.00 \\
\hline 24 & 1.4 & 0.68 & 48.00 & -52.00 \\
\hline 27 & 1.5 & 0.98 & 65.00 & -35.00 \\
\hline 30 & 1.5 & 0.60 & 40.00 & -60.00 \\
\hline
\end{tabular}


Table : 4 Showing percentage of increase or decrease in the volume of testis on the operated side in comparison to contralateral control following ligation of the body of epididymis

\begin{tabular}{|c|c|c|c|c|}
\hline No of days & \multicolumn{2}{|c|}{ Volume of testis in $\mathrm{ml}$} & \multirow{2}{*}{$\begin{array}{l}\text { Volume of the } \\
\text { experimental testis } \\
\text { expressed as \% of } \\
\text { control } \\
100.00 \\
\end{array}$} & \multirow{2}{*}{$\begin{array}{l}\text { Percentage of } \\
\text { increase or } \\
\text { decrease in size }\end{array}$} \\
\hline 3 & 1.4 & 1.40 & & \\
\hline 6 & 1.3 & 1.30 & 100.00 & -- \\
\hline 9 & 1.5 & 1.50 & 100.00 & -- \\
\hline 12 & 1.7 & 2.05 & 120.00 & +20.00 \\
\hline 15 & 1.5 & 2.13 & 142.00 & +42.00 \\
\hline 18 & 1.5 & 2.11 & 140.00 & +40.00 \\
\hline 21 & 1.5 & 1.32 & 88.00 & -12.00 \\
\hline 24 & 1.5 & 1.30 & 87.00 & -13.00 \\
\hline 27 & 1.6 & 1.20 & 75.00 & -25.00 \\
\hline 30 & 1.6 & 0.78 & 49.00 & -51.00 \\
\hline
\end{tabular}

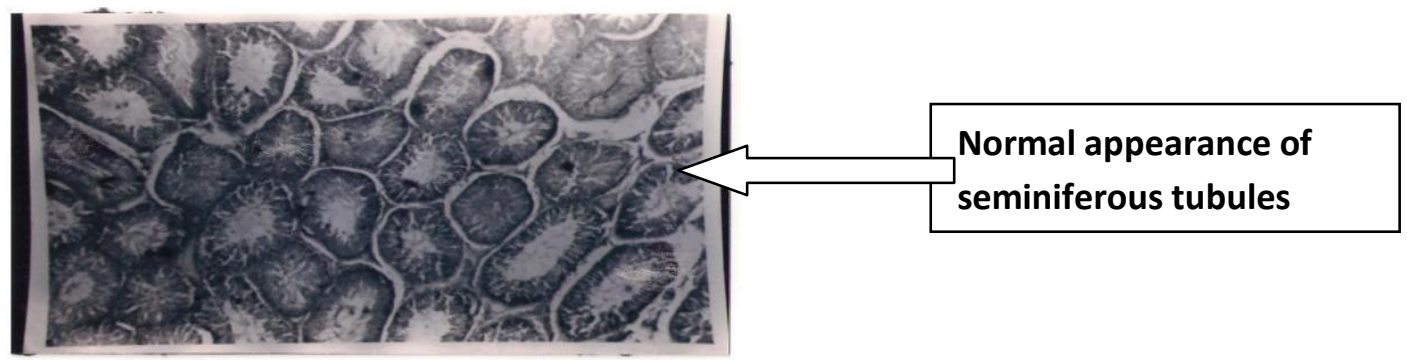

Fig 1: Photomicrograph of Testis 6 days after ligation of head of epididymis

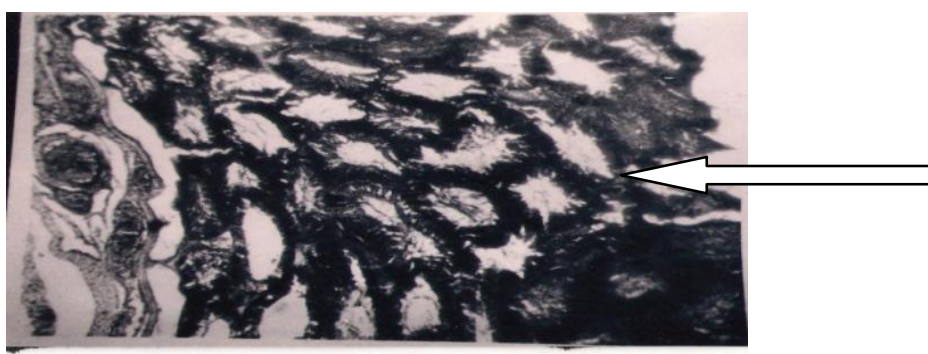

Degeneration of seminiferous

tubules

Fig 2: Photomicrograph of Testis 30 days after ligation of head of epididymis

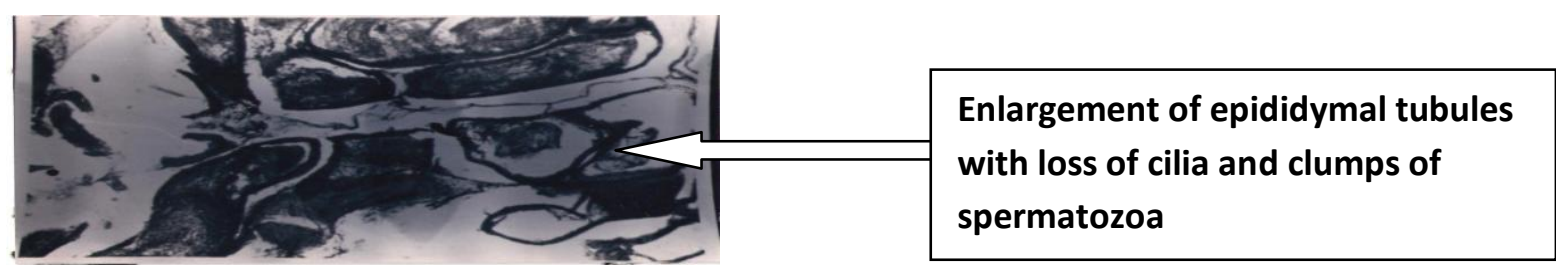

Fig 3 :Photomicrograph of Epididymis 15 days after ligation of head of epididymis

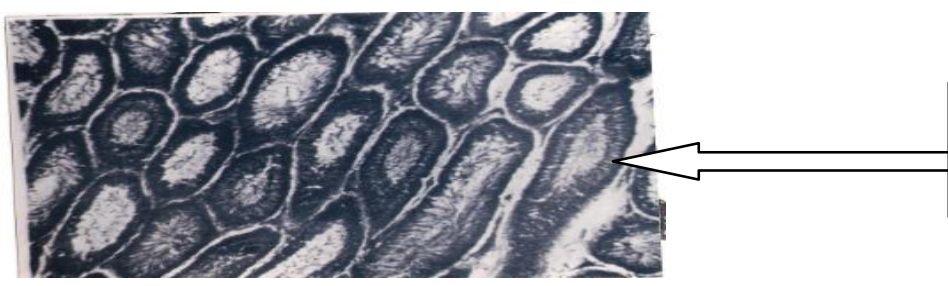

Increase in diameter of tubules with various degrees of shedding of

Fig 4: Photomicrograph of Testis 15 days after ligation of body of epididymis 


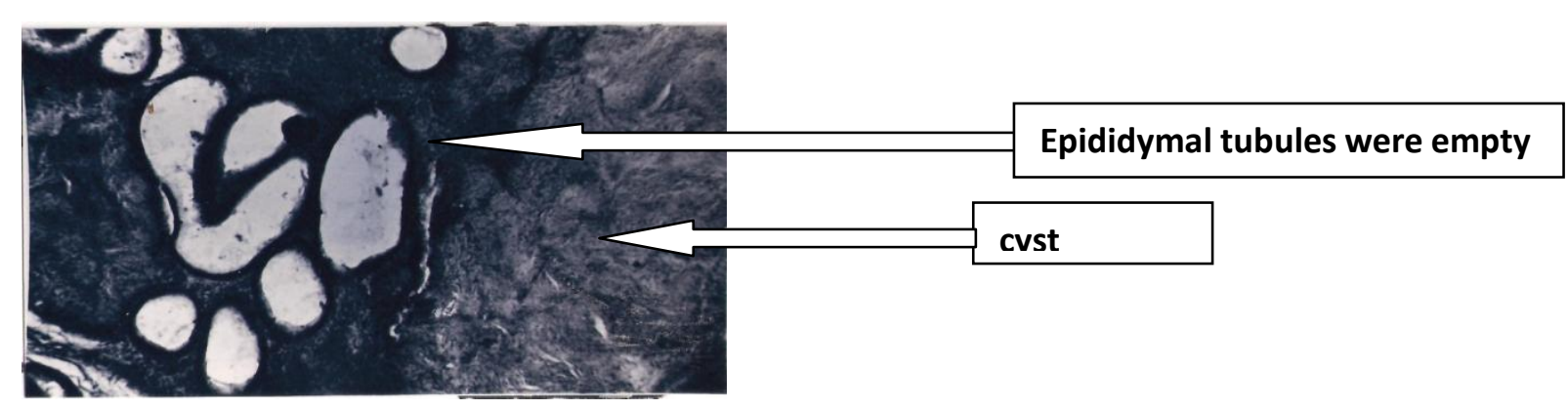

Fig 5: Photomicrograph of Epididymis 30 days after ligation of body of epididymis 